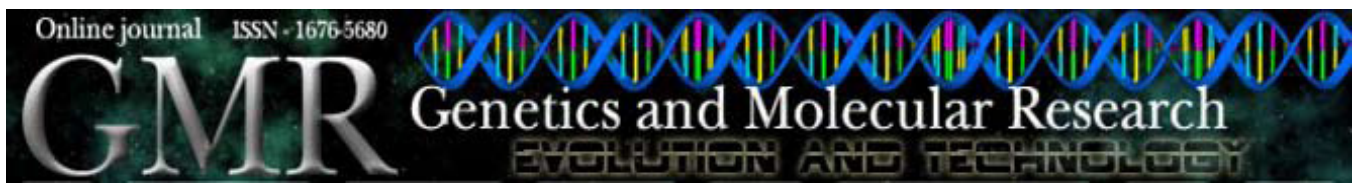

\title{
Evaluation of TFAM and FABP4 gene polymorphisms in three lines of Nellore cattle selected for growth
}

\author{
D.R. Ayres ${ }^{1}$, F.R.P. Souza ${ }^{1}$, M.E.Z. Mercadante ${ }^{2}$, L.F.S. Fonseca ${ }^{1}$, \\ H. Tonhati' ${ }^{1}$, J.N.S.G. Cyrillo ${ }^{2}$, S.F.M. Bonilha ${ }^{2}$ and L.G. Albuquerque ${ }^{1}$ \\ ${ }^{1}$ Departamento de Zootecnia, Faculdade de Ciências Agrárias e Veterinárias, \\ Universidade Estadual Paulista, Jaboticabal, SP, Brasil \\ ${ }^{2}$ Instituto de Zootecnia, Centro de Pesquisa em Pecuária de Corte, \\ Sertãozinho, SP, Brasil
}

Corresponding author: F.R.P. Souza

E-mail: fabiopablos@hotmail.com

Genet. Mol. Res. 9 (4): 2050-2059 (2010)

Received April 20, 2010

Accepted July 23, 2010

Published October 19, 2010

DOI 10.4238/vol9-4gmr850

\begin{abstract}
We analyzed the polymorphisms TFAM HaeIII, TFAM $M b o \mathrm{I}$ and FABP4 MspA1I in three Nellore lines selected for growth in order to evaluate how selection affects the frequencies of these polymorphisms and evaluate their association with growth and carcass traits in Zebu cattle. Birth, weaning and yearling weights, rump height, longissimus muscle area, backfat thickness, and rump fat thickness were analyzed. The sample was constituted of animals from two lines selected for yearling weight ( $\mathrm{NeS}$ and $\mathrm{NeT})$, and a control line $(\mathrm{NeC})$, established in 1980, at the São Paulo Instituto de Zootecnia. Two hundred and seventy-two heifers were genotyped for TFAM gene SNPs, and 325 heifers were genotyped for the FABP4 SNP. High frequencies were observed for the alleles A (TFAM HaeIII), C (TFAM MboI) and C (FABP4 MspA1I). Significant differences in allele frequencies between $\mathrm{NeS}$ and NeT were observed for the TFAM HaeIII, and between the line $\mathrm{NeT}$ and lines $\mathrm{NeC}$ and $\mathrm{NeS}$ for the FABP4 MspA1I SNP. Five haplotypes were observed for the two polymorphisms in the TFAM gene, haplotype AACC being the most frequent. None of the markers
\end{abstract}


evaluated separately or according to haplotype was significantly associated with the growth and carcass traits. The low frequencies of alleles that are associated with high marbling scores and thick subcutaneous fat in taurine breeds might explain the low means for these traits in Nellore cattle.

Key words: Beef cattle; QTL; SNP; Marker assisted selection; Zebu

\section{INTRODUCTION}

A selection experiment involving Zebu Nellore cattle was initiated in 1976 at the Estação Experimental de Zootecnia de Sertãozinho (São Paulo, Brazil) in order to determine the response of this breed to selection for body weight; the few published selection experiments carried out worldwide have used taurine breeds (Newman et al., 1973; Koch et al., 1994; Parnell et al., 1997). In 1980, three selection lines were created with these Nellore cattle. For the control line $(\mathrm{NeC})$, animals with differentials of zero or close to zero for yearling weight (stabilizing selection) were selected. The selection line $(\mathrm{NeS})$ and traditional line $(\mathrm{NeT})$ were selected animals with higher selection differentials for yearling weight (directional selection). The $\mathrm{NeC}$ and $\mathrm{NeS}$ lines were closed lines; the NeT line differed from the NeS line by sometimes receiving bulls from other herds, including commercial herds. The current performance of the $\mathrm{NeC}$ line is considered to be representative of the performance of the population existing in the 1970s.

Selection for growth traits may affect the frequencies of many genes involved in the expression of these traits. In this regard, the three herds provide a great opportunity to identify the regions of the genome that are altered by selection, providing information about genotypephenotype associations and allowing the identification of quantitative trait loci (QTLs) for productive traits.

Mitochondrial transcription factor A (TFAM), also known as $m t T F A, m t T F 1, T C F-6$, or $T C F 6 L 2$, is a nuclear transcription activator that is necessary for the initiation of transcription and replication of mtDNA in mammals and is associated with mitochondrial biogenesis (Clayton, 2000; Amaral et al., 2007). In cattle, Jiang et al. (2005), studying a Wagyu x Limousin cross (Bos primigenius taurus), found two single-nucleotide polymorphisms (SNPs) in the promoter region of the TFAM gene. The first SNP, an A/C transversion (TFAM HaeIII), was located at position -1220 of the TFAM gene, only $9 \mathrm{bp}$ from the second SNP, a C/T transition (TFAM MboI) at position -1212. Both polymorphisms and their haplotypes were found to be associated with marbling ( $\mathrm{P}=0.0153$ for $\mathrm{A} / \mathrm{C}, \mathrm{P}=0.0026$ for $\mathrm{C} / \mathrm{T}$, and $\mathrm{P}=0.0004$ for haplotype $)$ and subcutaneous fat depth (SFD) $(\mathrm{P}=0.0200$ for $\mathrm{A} / \mathrm{C}, \mathrm{P}=0.0039$ for $\mathrm{C} / \mathrm{T}$, and $\mathrm{P}=0.0029$ for haplotype).

Fat acid binding protein 4 (FABP4) plays a role in lipid hydrolysis and intracellular fatty acid trafficking by interacting with and binding to hormone-sensitive lipase, the main enzyme involved in lipid catabolism (Shen et al., 1999; Tansey et al., 2003). Michal et al. (2006), studying Korean breeds and a Wagyu x Limousin F2 cross, identified an SNP in the FABP4 gene (FABP4 $M s p A 1 I)$ that was associated with carcass traits, affecting marbling score $(\mathrm{P}=0.0398)$ and SFD $(\mathrm{P}=0.0246)$.

Although the association of these gene polymorphisms with carcass traits has been studied in B. p. taurus cattle (Jiang et al., 2005; Michal et al., 2006), their association with 
growth and carcass traits in Nellore cattle (B. p. indicus) has not been established. Therefore, our objective was to identify these gene polymorphisms in $B$. $p$. indicus animals in order to determine how selection for growth affects the frequencies of these polymorphisms, and to evaluate their association with growth and carcass traits based on information obtained from the Breeding Program of the Instituto de Zootecnia, São Paulo, Brazil.

\section{MATERIAL AND METHODS}

\section{Animals}

The experiments were carried out in accordance with humane animal care and handling procedures, according to the guidelines of the State of São Paulo in Brazil (law No. 11.977). Heifers born between 2003 and 2005, belonging to three Nellore lines from the Centro de Pesquisa em Pecuária de Corte, a research unit of the Instituto de Zootecnia, in the northern region of the State of São Paulo, were used. These animals are part of the breeding program initiated in 1978 and have been divided into three herds since 1980: NeS, NeT and $\mathrm{NeC}$. In the $\mathrm{NeS}$ and NeT lines, males are selected for higher standard weight at 378 days of age (W378) after performance testing in feedlots, and females are selected for standard weight at 550 days of age (W550) on pasture. In the $\mathrm{NeC}$ line, animals are selected based on W378 and W550 close to the average (stabilizing selection). The $\mathrm{NeC}$ and $\mathrm{NeS}$ herds are closed lines, whereas the $\mathrm{NeT}$ line differs from the NeS line by occasionally receiving bulls from other herds, including commercial herds. The mean breeding values for yearling weight of animals born over the last four years (2004 to 2007), corresponding to 5.5 generations of selection for growth, are $0.2,49.5$ and $55.3 \mathrm{~kg}$ for the $\mathrm{NeC}, \mathrm{NeS}$ and $\mathrm{NeT}$ lines, respectively (Razook and Mercadante, 2007).

For the SNPs of the TFAM gene, 272 heifers were genotyped, including 42 from the $\mathrm{NeC}$ herd, 93 from the NeS herd and 137 from the NeT herd. For the FABP4 gene, 325 heifers were genotyped, including 40 from the $\mathrm{NeC}$ herd, 112 from the NeS herd and 173 from the NeT herd.

\section{Traits studied}

Birth weight, weaning weight (standardized at 210 days of age, W210) and yearling weight (standardized at 550 days of age, W550) are obtained as part of the breeding program. Yearling rump height (H550) is measured at the time of recording the weight at 550 days.

Ultrasound records were obtained at an average of $22 \pm 2.5$ months of age. Crosssectional ultrasound images obtained from the region between the 12th and 13th rib on the longissimus dorsi muscle were used for the measurement of backfat thickness (BF) and longissimus muscle area (LMA). Rump fat thickness (RF) was measured between the hood and pin bones over the intersection between the gluteus medius and biceps femoris muscles. Two ultrasound systems were used: Aloka 500V (Corometrics Medical Systems, Inc., Wallingford, CT, USA) equipped with a linear 3.5-MHz transducer (depth: $17.5 \mathrm{~cm}$; Aloka Co. Ltd., Tokyo, Japan), and Pie Medical 401347 - Aquila (Esaote Europe B.V., Maastricht, The Netherlands) equipped with a linear 3.5-MHz transducer (depth: $18 \mathrm{~cm}$ ). Vegetable oil and a standoff pad were used for image acquisition to guarantee acoustic contact between the linear transducer and the body of the animal. The images were saved and then interpreted using the Echo Image Viewer 1.0 software (Pie Medical Equipment B.V. Maastricht, The Netherlands). 


\section{Genotyping}

Blood samples $(5 \mathrm{~mL})$ were collected from each animal by puncture of the jugular vein into Vacutainer tubes containing $7.5 \mathrm{mg}$ EDTA. Genomic DNA was extracted according to the protocol of Zadworny and Kuhnlein (1990).

The primers used for amplification of the promoter region of the TFAM gene were based on the primer sequence described by Jiang et al. (2005). The primer sequences described by Michal et al. (2006) were used for amplification of the FABP4 gene. The amplification reactions were carried out in a final volume of $25 \mu \mathrm{L}$, containing $100 \mathrm{ng}$ DNA, $15 \mathrm{pM}$ of each primer, $1 \mathrm{X}$ PCR buffer, $1.5 \mathrm{mM} \mathrm{MgCl}_{2}, 100 \mu \mathrm{M}$ dNTPs, and $1 \mathrm{U}$ Taq DNA polymerase (Fermentas International, Inc., Burlington, Ontario, Canada). Polymerase chain reaction (PCR) was carried out in a Biometra T thermocycler (Biometra Biomedizinische Analytik GmbH, Goettingen, Germany). An annealing temperature of $55.7^{\circ} \mathrm{C}$ was used for the TFAM gene and of $62.5^{\circ} \mathrm{C}$ for the $F A B P 4$ gene. The restriction enzymes $\mathrm{HaeIII}$ and $\mathrm{MboI}$ (Fermentas International, Inc.) were used for the detection of SNPs in the TFAM gene fragment, whereas MspA1I (New England Biolabs, Inc., Ipswich, MA, USA) was used for the FABP4 SNP. For enzymatic digestion, $5 \mu \mathrm{L}$ PCR product was mixed with $1 \mathrm{X}$ reaction buffer and $0.5 \mathrm{U}$ enzyme in a final reaction volume of 15 $\mu \mathrm{L}$. The digestion products of the TFAM gene were separated by electrophoresis ( $100 \mathrm{~V}$ for $2 \mathrm{~h}$ ) on $4 \%$ agarose gel stained with ethidium bromide. A $2 \%$ agarose gel was used for separation of the digestion products of the FABP4 gene. The fragments were visualized under an ultraviolet transilluminator and photographed using the Kodak Gel-Logic 100 imaging system. The length of the resulting fragments was determined with the Kodak Molecular Imaging software, using a 100-bp DNA ladder as a molecular standard (Invitrogen, Carlsbad, CA, USA).

\section{Statistical analysis}

The Fisher exact test was applied to compare gene frequencies between the three selection lines using the population differentiation module of the Genepop program, version 3.4 (http://genepop.curtin.edu.au/). A P value $\leq 0.05$ was considered to be significant.

The association between the polymorphisms and traits was analyzed using the PROC MIXED procedure of the SAS/STAT 9.1.3 program (SAS Institute, Inc., Cary, NC, USA). The model included genotype marker (TFAM HaeIII, TFAM MboI, and FABP4 MspA1I), contemporary group (birth year x line $, 1, \ldots, 9)$ and month of birth (September, October, November) as classificatory effects, dam's age and age at recording (only for H550 and the carcass measures LMA, BF and RF) as linear covariates, and random effect of sire $(1, \ldots, 41)$.

Additive and dominance effects were tested when a genotype marker presented a value close to significance $(\mathrm{P}<0.05)$ for a given trait. The additive covariates were 0,1 and 2 in order to take into account the number of allele variants for TFAM HaeIII (AA, AC, CC), TFAM MboI (CC, CT, TT) and FABP4 MspA1I (CC, CG, GG) according to Esmailizadeh et al. (2008). In the dominance test, another covariate was added (value of 0 for homozygotes and value of 1 for heterozygotes) and a significant result for this covariate was interpreted as evidence of a dominance effect.

\section{RESULTS}

The means and standard deviations obtained for each trait in the sample genotyped for 
FABP4 polymorphism, according to selection line, are shown in Table 1. In general, the NeS and $\mathrm{NeT}$ selection lines presented higher means for all traits, except for BF and RF.

Table 1. Least square means (standard error) of the traits analyzed in 325 animals of the three Nellore selection lines genotyped for FABP4 polymorphism.

\begin{tabular}{lccc}
\hline Trait & NeC $(40$ animals $)$ & NeS $(112$ animals $)$ & NeT $(173$ animals $)$ \\
\hline BW $(\mathrm{kg})$ & $25.5(0.7)^{\mathrm{b}}$ & $30.9(0.5)^{\mathrm{a}}$ & $30.7(0.5)^{\mathrm{a}}$ \\
W210 $(\mathrm{kg})$ & $154.4(3.4)^{\mathrm{b}}$ & $190.1(2.0)^{\mathrm{a}}$ & $186.5(1.6)^{\mathrm{a}}$ \\
W550 $(\mathrm{kg})$ & $259.8(4.7)^{\mathrm{c}}$ & $325.3(3.0)^{\mathrm{b}}$ & $297.5(2.5)^{\mathrm{a}}$ \\
H550 $(\mathrm{cm})$ & $127.8(0.7)^{\mathrm{c}}$ & $136.1(0.5)^{\mathrm{b}}$ & $131.8(0.4)^{\mathrm{a}}$ \\
LMA $\left(\mathrm{cm}^{2}\right)$ & $45.1(0.9)^{\mathrm{a}}$ & $48.2(0.5)^{\mathrm{b}}$ & $45.3(0.4)^{\mathrm{a}}$ \\
BF $(\mathrm{mm})$ & $2.1(0.2)^{\mathrm{b}}$ & $1.7(0.1)^{\mathrm{a}}$ & $1.6(0.1)^{\mathrm{a}}$ \\
RF $(\mathrm{mm})$ & $3.8(0.2)^{\mathrm{a}}$ & $3.6(0.2)^{\mathrm{a}}$ & $3.5(0.1)^{\mathrm{a}}$ \\
\hline
\end{tabular}

$\mathrm{NeC}=$ control line; $\mathrm{NeS}=$ selection line; $\mathrm{NeT}=$ traditional line; $\mathrm{BW}=$ birth weight $\mathrm{W} 210, \mathrm{~W} 550=$ weight at 210 and 550 days of age; $\mathrm{H} 550=$ rump height; $\mathrm{LMA}=$ longissimus muscle area; BF = backfat thickness, RF: rump fat thickness. Values followed by different letters in the same row differ significantly $(\mathrm{P}<0.01)$.

The length of the TFAM gene fragment amplified by PCR was $801 \mathrm{bp}$ and that of the FABP4 gene fragment was $452 \mathrm{bp}$. Digestion of the TFAM fragment with HaeIII identified the polymorphism at position -1220 in the TFAM gene and resulted in two digestion patterns, originating three genotypic classes (AA, AC, CC; Figure 1). The first pattern characterizing allele A consisted of fragments of 152,187 and $462 \mathrm{bp}$. The second pattern characterizing allele $\mathrm{C}$ consisted of fragments of 83, 104, 152, and $462 \mathrm{bp}$. The heterozygote AC consisted of fragments of 83,104,152, 187, and $462 \mathrm{bp}$. The use of $\mathrm{MboI}$ permitted the identification of the polymorphism at position -1212 in the TFAM gene and resulted in two digestion patterns of the TFAM fragment. The first pattern consisted of fragments of 55, 68, 135, and $543 \mathrm{bp}$, characterizing allele $\mathrm{C}$, and the second pattern consisted of fragments of 55, 68, 135, 241, and $302 \mathrm{bp}$, characterizing allele $\mathrm{T}$. The heterozygote $\mathrm{CT}$ consisted of fragments of 55, 68, 135, 241, 302, and $543 \mathrm{bp}$. Digestion of the FABP4 gene with MspA1I permitted us to distinguish two alleles: allele $\mathrm{C}$ consisting of the intact 452-bp fragment, and allele $\mathrm{G}$ consisting of 100- and 352-bp fragments. Genotype TT of the TFAM MboI marker and genotype GG of the FABP4 MspA1I marker were not identified in any of the selection lines (Figure 1).

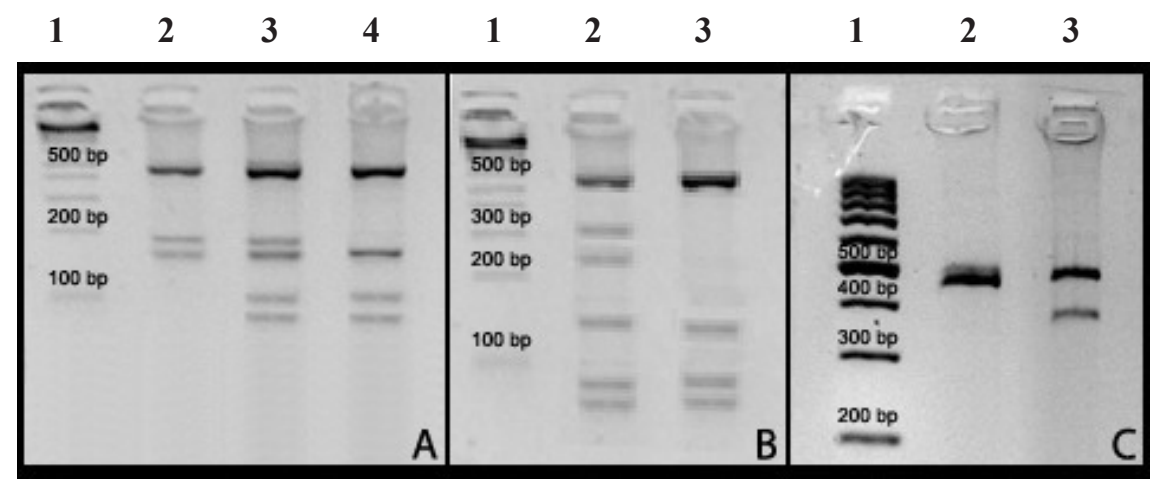

Figure 1. Agarose gels showing the genotypes of TFAM and FABP4 SNPs in Nellore animals. A. Polymorphism TFAM HaeIII: lane $1=100$-bp DNA ladder; lane $2=\mathrm{AA}$ animals; lane $3=\mathrm{AC}$ animals; lane $4=\mathrm{CC}$ animals. B. Polymorphism TFAM MboI: lane $1=100-b p$ DNA ladder; lane $2=\mathrm{CT}$ animals; lane $3=\mathrm{CC}$ animals. C. Polymorphism FABP4 MspA1I: lane $1=100$-bp DNA ladder; lane $2=\mathrm{CC}$ animals, and lane $3=\mathrm{CG}$ animals. 
Alleles A, C and C of the TFAM HaeIII, TFAM MboI and FABP4 MspA1I markers, respectively, were the most frequent in all selection lines, with a frequency higher than 0.84. The TFAM HaeIII and FABP4 MspA1I markers presented greater heterozygosity in the $\mathrm{NeC}$ and NeS lines. Greater heterozygosity of the TFAM MboI marker was observed in the lines selected for higher weight (NeS and NeT; Table 2).

\begin{tabular}{|c|c|c|c|c|c|}
\hline \multirow{2}{*}{$\begin{array}{l}\text { Marker/line } \\
\text { TFAM HaeIII }\end{array}$} & \multicolumn{3}{|c|}{ Genotype frequency } & \multicolumn{2}{|c|}{ Allele frequency } \\
\hline & AA & $\mathrm{AC}$ & $\mathrm{CC}$ & A & $\mathrm{C}$ \\
\hline $\mathrm{NeC}$ & 0.79 & 0.21 & 0 & 0.90 & 0.10 \\
\hline $\mathrm{NeS}$ & 0.72 & 0.26 & 0.02 & 0.84 & 0.16 \\
\hline $\mathrm{NeT}$ & 0.88 & 0.12 & 0 & 0.94 & 0.06 \\
\hline TFAM MboI & $\mathrm{CC}$ & $\mathrm{CT}$ & TT & $\mathrm{C}$ & $\mathrm{T}$ \\
\hline $\mathrm{NeC}$ & 1.0 & 0 & 0 & 1.0 & 0 \\
\hline $\mathrm{NeS}$ & 0.93 & 0.07 & 0 & 0.96 & 0.04 \\
\hline $\mathrm{NeT}$ & 0.95 & 0.05 & 0 & 0.98 & 0.02 \\
\hline FABP4 MspA1I & $\mathrm{CC}$ & CG & GG & $\mathrm{C}$ & G \\
\hline $\mathrm{NeC}$ & 0.80 & 0.20 & 0 & 0.90 & 0.10 \\
\hline $\mathrm{NeS}$ & 0.89 & 0.11 & 0 & 0.95 & 0.05 \\
\hline $\mathrm{NeT}$ & 0.99 & 0.01 & 0 & 0.99 & 0.01 \\
\hline
\end{tabular}

$\mathrm{NeC}=$ control line $; \mathrm{NeS}=$ selection line $; \mathrm{NeT}=$ traditional line.

Only five haplotypes of the TFAM promoter polymorphisms were observed in the Nellore breed, with haplotype AACC being the most frequent in all selection lines, followed by haplotype ACCC. The greatest haplotype diversity was observed in the NeS line, which presented the five haplotypes detected in this study. The least frequent haplotypes were ACCT and CCCC (Table 3).

Table 3. Frequencies of TFAM HaeIII and TFAM MboI SNP haplotypes in the three Nellore selection lines.

\begin{tabular}{lcc}
\hline Selection line & Haplotype & Frequency \\
\hline $\mathrm{NeC}$ & AACC & 0.78 \\
& ACCC & 0.22 \\
\hline $\mathrm{NeS}$ & AACC & 0.67 \\
& AACT & 0.04 \\
& ACCC & 0.24 \\
& ACCT & 0.01 \\
$\mathrm{NeT}$ & CCCC & 0.03 \\
& AACC & 0.83 \\
& AACT & 0.05 \\
\hline
\end{tabular}

$\mathrm{NeC}=$ control line $; \mathrm{NeS}=$ selection line; $\mathrm{NeT}=$ traditional line.

The Fisher exact test revealed a significant difference in the allele frequencies of TFAM HaeIII between the NeS and NeT lines. For FABP4 MspA1I, a significant difference was observed between the open $\mathrm{NeT}$ line and the closed lines $\mathrm{NeC}$ and $\mathrm{NeS}$. No difference was observed between the $\mathrm{NeC}$ and $\mathrm{NeS}$ lines. For TFAM MboI, no significant difference in allele frequency was observed between the various lines (Table 4).

\begin{tabular}{|c|c|c|c|}
\hline \multirow[t]{2}{*}{ Pair of populations } & \multicolumn{3}{|c|}{$\mathrm{P}$} \\
\hline & TFAM HaeIII & TFAM MboI & FABP4 MspA1I \\
\hline $\mathrm{NeC} v s \mathrm{NeS}$ & 0.44 & 0.32 & 0.20 \\
\hline $\mathrm{NeC} v s \mathrm{NeT}$ & 0.14 & 0.20 & $<0.001$ \\
\hline $\mathrm{NeS} v s \mathrm{NeT}$ & $<0.001$ & 1.0 & $<0.001$ \\
\hline
\end{tabular}

$\mathrm{NeC}=$ control line $; \mathrm{NeS}=$ selection line $; \mathrm{NeT}=$ traditional line. 
None of the markers evaluated separately or according to haplotype exerted significant effects on the growth and carcass traits studied. A marker presenting an effect close to significance was TFAM HaeIII on LMA, with animals with genotype AA showing a higher mean for this trait, followed by AC and CC animals (Table 5). Analysis of additive effects indicated that allele $\mathrm{A}$ is associated with an increase of $4.1 \pm 1.9 \mathrm{~cm}^{2}$ in LMA $(\mathrm{P}=0.03)$. The dominance effect of allele A was $3.9 \pm 2.0(\mathrm{P}=0.06)$. However, these estimates are of low accuracy because of the small number of animals with genotype CC in the population. Nominal $P$ values, least square means and standard errors obtained for the effects of the haplotypes of the TFAM gene SNPs are shown in Table 6.

\begin{tabular}{|c|c|c|c|c|c|c|c|}
\hline \multirow[t]{2}{*}{ Marker } & \multicolumn{6}{|c|}{ Trait } & \multirow[b]{2}{*}{$\mathrm{RF}$} \\
\hline & BW & W210 & W550 & $\mathrm{H} 550$ & LMA & $\mathrm{BF}$ & \\
\hline \multicolumn{8}{|c|}{ TFAM HaeIII } \\
\hline $\mathrm{P}$ & 0.93 & 0.37 & 0.41 & 0.82 & 0.09 & 0.67 & 0.32 \\
\hline AA & $29.13(0.40)$ & $177.66(2.03)$ & $292.97(2.61)$ & $131.58(0.37)$ & $46.6(0.6)$ & $1.9(0.1)$ & $3.8(0.1)$ \\
\hline $\mathrm{AC}$ & $29.32(0.59)$ & $180.66(3.33)$ & 297.97 (4.04) & $131.90(0.56)$ & $46.4(0.9)$ & $2.0(0.2)$ & $3.9(0.2)$ \\
\hline $\mathrm{CC}$ & $29.60(2.51)$ & 195.76 (15.39) & 303.91 (17.94) & $132.12(2.44)$ & $38.5(3.7)$ & $1.4(0.8)$ & $2.4(1.0)$ \\
\hline \multicolumn{8}{|c|}{ TFAM MboI } \\
\hline $\mathrm{P}$ & 0.78 & 0.82 & 0.83 & 0.41 & 0.31 & 0.58 & 0.59 \\
\hline $\mathrm{CC}$ & $29.18(0.39)$ & $178.44(1.90)$ & $294.01(2.47)$ & $131.68(0.36)$ & $46.5(0.6)$ & $2.0(0.1)$ & $3.9(0.2)$ \\
\hline $\mathrm{CT}$ & 28.88 (1.9) & $176.98(6.4)$ & $295.57(7.68)$ & $130.84(1.05)$ & $48.27(1.7)$ & $2.2(0.4)$ & $4.1(0.5)$ \\
\hline \multicolumn{8}{|c|}{ FABP4 MspA1I } \\
\hline $\mathrm{P}$ & 0.57 & 0.30 & 0.58 & 0.79 & 0.12 & 0.96 & 0.56 \\
\hline $\mathrm{CC}$ & $29.11(0.3)$ & $177.56(1.5)$ & $294.50(2.1)$ & $131.83(0.3)$ & $46.39(0.3)$ & $1.78(0.1)$ & $3.58(0.1)$ \\
\hline CG & $28.63(0.83)$ & $172.64(4.5)$ & $291.42(5.4)$ & $131.63(0.7)$ & $44.55(1.12)$ & $1.79(0.2)$ & $3.78(0.3)$ \\
\hline
\end{tabular}

For abbreviations, see legend to Table 1.

Table 6. Nominal P values, least square means and standard errors (in parentheses) obtained for the effects of the TFAM HaeIII and TFAM MboI SNP haplotypes on growth and carcass traits in Nellore cattle.

\begin{tabular}{lccccccc}
\hline Haplotype & \multicolumn{7}{c}{ Trait } \\
\cline { 2 - 7 } & \multicolumn{1}{c}{ BW } & W210 & W550 & H550 & LMA & BF & RF \\
\hline P & 0.48 & 0.73 & 0.69 & 0.91 & 0.15 & 0.83 & 0.61 \\
AACC & $29.13(0.41)$ & $177.70(2.05)$ & $292.87(2.63)$ & $131.61(0.38)$ & $46.61(0.66)$ & $2.03(0.15)$ & $3.85(0.19)$ \\
AACT & $29.46(1.14)$ & $177.01(6.79)$ & $296.44(8.04)$ & $130.80(1.11)$ & $47.61(1.77)$ & $2.29(0.40)$ & $4.04(0.50)$ \\
ACCC & $29.44(0.59)$ & $180.75(3.37)$ & $298.23(4.07)$ & $131.91(0.56)$ & $46.29(9.5)$ & $2.15(0.21)$ & $4.00(2.27)$ \\
ACCT & $23.17(3.44)$ & $175.97(21.73)$ & $285.54(25.00)$ & $131.22(3.39)$ & $53.06(5.30)$ & $1.79(1.21)$ & $4.80(1.51)$ \\
CCCC & $29.17(2.51)$ & $195.61(15.45)$ & $303.17(18.03)$ & $132.09(2.45)$ & $38.58(3.79)$ & $1.38(0.86)$ & $2.49(1.08)$ \\
\hline
\end{tabular}

For abbreviations, see legend to Table 1

\section{DISCUSSION}

In this study, we identified the TFAM gene polymorphisms described by Jiang et al. (2005) in three Nellore (B. p. indicus) lines selected for growth, with a predominance of alleles A and $\mathrm{C}$ of the TFAM HaeIII and TFAM MboI SNPs, respectively.

Allele A of the TFAM HaeIII presented a frequency of 0.90 in line $\mathrm{NeC}, 0.84$ in line $\mathrm{NeS}$, and 0.94 in line NeT. For the TFAM MboI SNP, allele C presented a frequency of 1.0 in line $\mathrm{NeC}, 0.96$ in line $\mathrm{NeS}$, and 0.98 in line NeT. Thus, the frequency of allele $\mathrm{C}$ of the TFAM HaeIII SNP and the frequency of allele T of the TFAM MboI SNP do not overcome 0.16. In 
a study involving a commercial Nellore line, higher frequencies of alleles $\mathrm{A}$ and $\mathrm{C}$ were also observed for the TFAM HaeIII and TFAM MboI SNPs, with a frequency of alleles A and C of 0.87 and 0.94 , respectively (Rezende et al., 2008). In a Wagyu x Limousin (B. p. taurus) cross, the differences between the frequencies of the alleles were smaller. Allele $\mathrm{C}$ of TFAM HaeIII had a frequency of 0.56 , and allele C of TFAM MboI SNP had a frequency of 0.61 (Jiang et al., 2005). These differences between the frequencies of the alleles in both TFAM SNPs suggest that the mutation that gave origin to these polymorphisms is exclusive to B. $p$. taurus and may have occurred after the separation of B. p. taurus and B. p. indicus. The identification of different alleles in Nellore may be due to the presence of animals with some level of hybridization (B. p. taurus x B. p. indicus).

Despite the apparently strong linkage disequilibrium, the TFAM gene polymorphisms resulted in five haplotypes in Wagyu x Limousin crosses, including haplotype CCCC with a frequency of 0.31 , CACT with a frequency of 0.45 , AATT with a frequency of 0.14 , AACT with a frequency of 0.05 , and CACC with a frequency of 0.03 (Jiang et al., 2005). A predominance of haplotype AACC, which had not been described in cattle before, and haplotype CACC, which is less frequent in the Wagyu x Limousin cross, was observed in Nellore cattle. Haplotype AATT, described in a Wagyu x Limousin line, was not detected in Nellore cattle.

The significant differences in the allele frequencies of the TFAM HaeIII SNP between the $\mathrm{NeS}$ and NeT lines may be explained by the nature of the NeS line, which, because it is a closed line, theoretically possesses the same genetic composition as the original herd from 1978, considering the lack of gene flow from other herds. The higher frequency of allele T of the TFAM MboI SNP in the lines selected for higher growth differentials (NeS and $\mathrm{NeT}$ ) and the fixation of allele $\mathrm{C}$ in the $\mathrm{NeC}$ line may reflect the differential that this allele provides during growth selection. However, the Fisher exact test showed that this difference was not significant and statistical analysis revealed no association between the polymorphism and growth traits. Thus, the frequencies of this SNP might be under the effect of genetic drift and the lack of allele $\mathrm{T}$ in the $\mathrm{NeC}$ line might be due to the smaller number of animals and a greater effect of genetic drift on this line.

The higher diversity of haplotypes in line NeS also may be explained by the lower influence of the genetic drift in this closed line, which have more animals than the $\mathrm{NeC}$ line. Thus, line NeS have more haplotypes of $B$. p. taurus than line NeT and a smaller effect of genetic drift than line $\mathrm{NeC}$, which lost some haplotypes.

Jiang et al. (2005), studying a Wagyu x Limousin line, demonstrated that two polymorphisms and haplotypes were associated with greater SFD and marbling. Genotype CC of the TFAM HaeIII SNP and genotype CC of the TFAM MboI SNP, as well as haplotype CCCC, were associated with higher means for both traits.

In a Nellore commercial line, Rezende et al. (2008) found associations between the TFAM MboI SNP and RF, but in contrast with Jiang et al. (2005), TT animals had the highest mean for this trait, followed by CT animals. As in our study, Rezende et al. (2008) found a value close to significance between the TFAM HaeIII SNP and LMA. Thus, the predominance of allele A of the TFAM HaeIII SNP and of haplotype AACC in Nellore animals may explain the tendency of this breed to deposit less subcutaneous fat, and present a lower marbling score when compared to most taurine breeds (Cundiff, 2004); it may also explain the borderline significant value obtained for LMA, since there is evidence of a negative correlation between LMA and BF (Cyrillo et al., 2005). 
In fact, both SNPs in the TFAM gene promoter, jointly or separately, lead to gain/ loss of six putative-binding sites for transcription factors relevant to fat deposition and energy metabolism. Among the sites are: 1) tal-1a/ E47heterodimer; 2) heterodimers of the bHLH transcription factors HAND2 (Thing2) and E12; 3) zinc finger protein RP58 (ZNF238), which is associated preferentially with heterochromatin; 4) transcription factor cAMP-response element-binding protein (CREB), which may induce or block adipocyte differentiation (Reusch and Klemm, 2002); 5) nuclear factor 1, which is essential for the expression of stearoyl-CoA desaturase 1 gene during preadipocyte differentiation (Singh and Ntambi, 1998), and 6) the RAR-related orphan receptor a1, or RORa1, which forms a part of the multifactorial regulatory mechanisms that control expression of the PPAR $\gamma$ gene, which has a central role in promoting and maintaining the adipocyte phenotype (Sundvold and Lien, 2001).

We observed the FABP4 MspA1I polymorphism in the three Nellore lines selected for growth and a predominance of allele C (Michal et al., 2006). Rezende et al. (2008), studying the same FABP4 SNP in a commercial Nellore line, also found a higher frequency of allele $\mathrm{C}$ (0.99). Allele $\mathrm{C}$ is also the most frequent allele in the Wagyu $\mathrm{x}$ Limousin cross, but the difference between allele frequencies is smaller than that observed in Nellore animals. In a Wagyu $\mathrm{x}$ Limousin line, the frequency of allele $\mathrm{G}$ was found to be 0.25 , whereas that of allele $\mathrm{C}$ was 0.75 (Michal et al., 2006). Similar to the TFAM gene, the low frequencies of allele G observed in Nellore animals suggest that the mutation that gave origin to this polymorphism is also exclusive to B. p. taurus and may have occurred after the separation of B. p. taurus and B. p. indicus.

The significant differences in the allele frequencies of the FABP4 MspA1I SNP between the closed lines $(\mathrm{NeC}$ and $\mathrm{NeS})$ and the open line $(\mathrm{NeT})$ also support the idea that this polymorphism is exclusive to $B$. $p$. taurus. Since no gene flow occurs between the $\mathrm{NeC}$ and $\mathrm{NeS}$ lines and other herds, the $\mathrm{G}$ allele is maintained more easily in these lines when compared to the NeT line and the commercial line studied by Rezende et al. (2008).

In a Wagyu x Limousin line, the presence of allele $\mathrm{G}$ of the FABP4 gene is associated with higher means for marbling and SFD. With respect to the latter trait, the highest mean was observed for the heterozygous CG genotype (Michal et al., 2006). The association of this SNP with carcass traits and the frequencies of its alleles in the Wagyu $x$ Limousin line suggest that this polymorphism is a promising marker for marker-assisted selection. However, the same does not apply to the Nellore cattle in our study, which presented a very low frequency of allele G; we could not establish a relationship of this allele with economic traits. Nevertheless, the low frequency of allele G of the FABP4 MspA1I SNP in Nellore cattle is compatible with the low marbling scores and $\mathrm{BF}$ observed in this breed.

In conclusion, the samples of Nellore cattle studied for these polymorphisms showed that this breed is characterized by higher frequencies of alleles A (TFAM HaeIII), C (TFAM $M b o \mathrm{I})$ and $\mathrm{C}$ (FABP4 MspA1I). The low frequencies of the other alleles probably mean that these polymorphisms are exclusive to B. p. taurus. Although the effects of these markers in Zebu cattle could not be established, probably because of the distribution of the alleles, the low frequencies of alleles that are associated with higher marbling scores and higher BF in B. p. taurus are compatible with the low means observed for these traits in Nellore animals.

\section{ACKNOWLEDGMENTS}

Research supported by Fundação de Amparo à Pesquisa do Estado de São Paulo (FAPESP), 
Conselho Nacional de Desenvolvimento Científico e Tecnológico (CNPq), and Coordenação de Aperfeiçoamento de Pessoal de Nível Superior (CAPES). We are indebted to the Instituto de Zootecnia for providing the cattle blood samples and the data set used in this study.

\section{REFERENCES}

Amaral A, Ramalho-Santos J and St John JC (2007). The expression of polymerase gamma and mitochondrial transcription factor A and the regulation of mitochondrial DNA content in mature human sperm. Hum. Reprod. 22: 1585-1596.

Clayton DA (2000). Transcription and replication of mitochondrial DNA. Hum. Reprod. 15 (Suppl 2): 11-17.

Cundiff LV (2004). Encyclopedia of Animal Science. In: Beef Cattle: Breeds and Genetics (Pond WG and Bell AW, eds.). Cornell University, Ithaca.

Cyrillo JNSG, Mercadante MEZ, Silva SL, Razook AG, et al. (2005). Estimativas de Parâmetros para Pesos, Alturas, Escores Visuais e Características de Carcaça Obtidas por Ultra-Som em Bovinos Nelore. In: XIX Reunión de la Asociación Latinoamericana de Producción Animal, Tampico, 564-566.

Esmailizadeh AK, Bottema CD, Sellick GS, Verbyla AP, et al. (2008). Effects of the myostatin F94L substitution on beef traits. J. Anim. Sci. 86: 1038-1046.

Jiang Z, Kunej T, Michal JJ, Gaskins CT, et al. (2005). Significant associations of the mitochondrial transcription factor A promoter polymorphisms with marbling and subcutaneous fat depth in Wagyu x Limousin F2 crosses. Biochem. Biophys. Res. Commun. 334: 516-523.

Koch RM, Cundiff LV and Gregory KE (1994). Cumulative selection and genetic change for weaning or yearling weight or for yearling weight plus muscle score in Hereford cattle. J. Anim. Sci. 72: 864-885.

Michal JJ, Zhang ZW, Gaskins CT and Jiang Z (2006). The bovine fatty acid binding protein 4 gene is significantly associated with marbling and subcutaneous fat depth in Wagyu x Limousin F2 crosses. Anim. Genet. 37: 400-402.

Newman JA, Rahnefeld GH and Fredeen HT (1973). Selection intensity and response to selection for yearling weight in selection in beef cattle. Can. J. Anim. Sci. 53: 1-12.

Parnell PF, Arthur PF and Barlow R (1997). Direct response to divergent selection for yearling growth rate in Angus cattle. Livest. Prod. Sci. 49: 297-304.

Razook AG and Mercadante MEZ (2007). Ganhos de Produtividade com o Uso de Touros Provados. In: Requisitos de Qualidade na Bovinocultura de Corte (Santos FAP, Moura JC and Faria VP, eds.). FEALQ (Fundação de Estudos Agrários Luiz de Queiroz), Piracicaba, 93-114.

Reusch JE and Klemm DJ (2002). Inhibition of cAMP-response element-binding protein activity decreases protein kinase B/Akt expression in 3T3-L1 adipocytes and induces apoptosis. J. Biol. Chem. 277: 1426-1432.

Rezende FM, Ferraz JBS, Silva SL, Balieiro JC, et al. (2008). Influência de Alguns Polimorfismos Genéticos Sobre Características de Carcaça em Bovinos da Raça Nelore. In: VII Simpósio Brasileiro de Melhoramento Animal, 10 e 11 de julho. Sociedade Brasileira de Melhoramento Animal, São Carlos, 1-4. Available at [http://sbmaonline.org.br/ anais/vii/trabalhos/pdfs/bc025.pdf]. Accessed October 13, 2010.

Shen WJ, Sridhar K, Bernlohr DA and Kraemer FB (1999). Interaction of rat hormone-sensitive lipase with adipocyte lipid-binding protein. Proc. Natl. Acad. Sci. U. S. A. 96: 5528-5532.

Singh MV and Ntambi JM (1998). Nuclear factor 1 is essential for the expression of stearoyl-CoA desaturase 1 gene during preadipocyte differentiation. Biochim. Biophys. Acta 1398: 148-156.

Sundvold H and Lien S (2001). Identification of a novel peroxisome proliferator-activated receptor (PPAR) gamma promoter in man and transactivation by the nuclear receptor RORalpha1. Biochem. Biophys. Res. Commun. 287: 383-390.

Tansey JT, Huml AM, Vogt R, Davis KE, et al. (2003). Functional studies on native and mutated forms of perilipins. A role in protein kinase A-mediated lipolysis of triacylglycerols. J. Biol. Chem. 278: 8401-8406.

Zadworny D and Kuhnlein U (1990). The identification of the kappa-casein genotype in Holstein dairy cattle using the polymerase chain reaction. Theor. Appl. Genet. 80: 631-634. 